\title{
Numerical Prediction of Extreme Precipitation over a Truly Complex Terrain of Nepal Himalaya
}

\author{
Sangeeta Maharjan \& Ram P. Regmi \\ National Atmospheric Resource and Environmental Research Laboratory (NARERL) \\ Central Department of Physics, Tribhuvan University, Kirtipur, Kathmandu, Nepal. \\ E-mail: sangeetamaharjan@gmail.com
}

\begin{abstract}
The predictability of extreme precipitation over truly complex terrain of Nepal Himalaya using Weather Research and Forecasting (WRF) Modeling System has been examined with the case study of record high precipitation (357 $\mathrm{mm}$ in 24-hours) over the Pokhara area on the day of 18 August 2001 initialized with NCEP Reanalysis Global Data sets of $1^{\circ} \times 1^{\circ}$ resolution without appreciating observation data assimilation. The model resolved the essential features of the precipitation pattern over the area although the model underestimated the reported amount of precipitation as much as $87 \mathrm{~mm}$. The difference may be attributed to the highly localized intense precipitation due to local effects. Significant improvement in the accuracy of prediction can be expected with detail regional meteorological data assimilation.
\end{abstract}

Keywords: Atmospheric modeling, extreme precipitation, orographic effect, Pokhara valley, rain capital.

\section{INTRODUCTION}

Nepal witnesses large spatial variation in annual rainfall ranging from less than $150 \mathrm{~mm}$ over Lomanthang area of Mustang Administrative Districts to more than 5,000 mm over Lumle area of Kaski Administrative District of Nepal (PANO 2009). Nepal receives about $80 \%$ of the total annual rainfall during monsoon season (June to September) (Shrestha 2000). The primary reason for occurrence of monsoon rain over the country is considered to be the development of depression over the Bay of Bengal and its movement towards the north (Nayava 1974, Lang \& Barros 2002). Eastern most part of country is drenched by the summer monsoon at the first and it advances to the west covering the whole country. Besides, the existing undulating topography in the country enhances orographic effect causing the unparallel spatial and temporal variations of the precipitation. As a result, the southern slope of Makalu range in Eastern Development Region, Jugal range in Central Development Region and south of the Annapurna Himalaya Range in Western Development Region are the areas where precipitation are significantly higher whereas Manang and Mustang Administrative District areas located over the rain shadows of the Annapurna Himalaya Range in the Western Development receive least rainfall (PANO 2009).

Indian monsoon has been extensively studied and occupies surplus literatures. However, only a few extensive studies are seen on the characteristics of monsoon over Nepal. Nayava (1980) has attempted to generalize the basic atmospheric circulation inducing monsoon rains over Nepal by analyzing the precipitation records from 168 stations distributed throughout the country. Likewise, Shrestha (2000) has analyzed an appreciable volume of rainfall records from 60 rain gauges scattered throughout the country for the period in between 1957-1988 and estimated the monsoon rainfall totals under $200 \mathrm{~cm}$ for the middle and high Himalaya regions. Lang and Barros (2002) examined the onset of monsoon in central Nepal for the two consecutive years 1999 and 2000. They found that the onset of monsoon was closely associated with the depressions in the Bay of Bengal. Kansakar et al. (2004) have derived the typical climatological patterns of monthly precipitation, classification of regimes by the orographic shapes and the magnitude of monthly precipitation based on 222 stations in the country. They stressed on the orographic induction as the important factor on the prevailing variation in precipitation pattern in the Himalayan region. Moreover, a few significant studies on the precipitation pattern over Central Nepal Himalaya are also apparent using satellite data acquired during Tropical Rainfall Measuring Mission (TRMM) (Lang \& Barros 2004, Islam et al. 2010, Shrestha et al. 2012). 


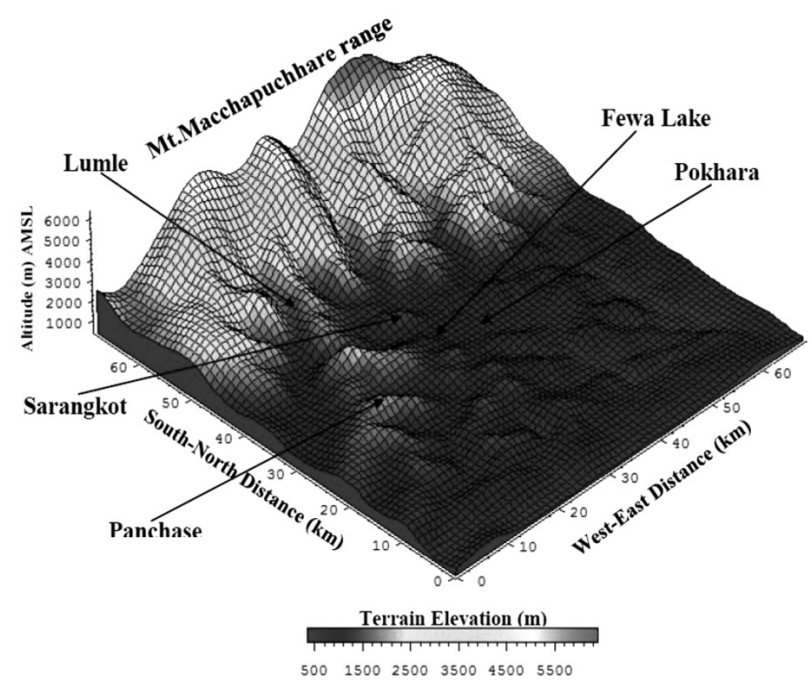

Fig. 1. Three-dimensional topographic view of Pokhara Valley and its immediate surroundings.

Pokhara valley (Fig.1) also known as the Rain Capital of Nepal receives the highest rainfall in the country. It is located in the southern slopes of Annapurna and Machhapuchare Himalaya. The annual average rainfall over the area is estimated at 3951.5 millimeters. On the 18 August 2001, Pokhara was drenched with $357 \mathrm{~mm}$ of rains within 24 hours. This is the most intense rainfall so far recorded (http://www.irha-h2o.org) over the area.

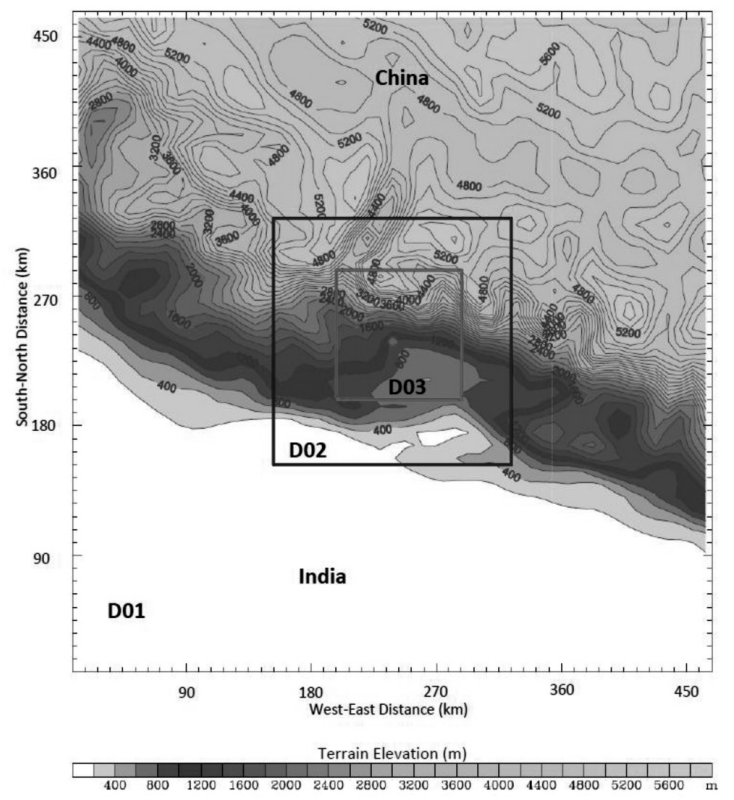

Fig. 2. Mesoscale domain configuration setup for numerical weather simulation over the area of Pokhara. The center of the calculation domains was set at Pokhara Airport indicated by the filled circle.
In this paper an attempt has been made understand the spatial and temporal distribution pattern of rainfall over the area on the day of 18 August 2001 with numerical simulation of weather situation over the area using Weather Research and Forecasting (WRF) Modeling System of version 3.5.1 (Michalakes et al. 1998, Skamarock et al. 2008). The WRF model is considered to be one of the most successful model for the reconstruction and forecasting of extreme weather situations over complex terrain (Vaid 2013, Chen et al. 2013, Ji et al. 2013, Deb et al. 2008, Dasari \& Challa, 2015, Afandi et al. 2013, Ibrahim \& Afandi 2014, Otkin \& Greenwald 2008). Furthermore, the model has been successfully implemented over Himalayan complex terrain to simulate weather events (Regmi 2013, Regmi \& Maharjan 2013, Regmi 2014a, Regmi 2014b, Maharjan \& Regmi 2014, Acharya et al. 2014).

\section{METHOLODGY}

WRF Modeling System version 3.5.1 (Michalakes et al. 1998, 2001, Skamarock et al. 2008) was configured with a triply nested two way interacting mesh having 51 x 51 horizontal grid points for outermost (D1) and inner (D2) domains with 9 and $3 \mathrm{~km}^{2}$ grid sizes, respectively, and the inner most domain (D3) was constructed with $70 \times 70$ grid points of size $1 \mathrm{~km}^{2}$ area (Fig. 2). For each of these domains 35 vertical levels were assigned. The lowest vertical level was set at 27 meter above the ground and the model top was set at $50 \mathrm{hPa}$. All the three domains were centered at the center of the Pokhara valley, the Pokhara Airport.

A 48 hours long simulation was performed initializing with horizontal resolution 6 hourly meteorological data from National Centers for Environmental Prediction (NCEP) and the 24-categories land use and 30 second terrain elevation data by United States Geological Survey (USGS) for the period of 0000 UTC 17 August 2001 to 0000 UTC 19 August 2001. The first 24 hours simulations were discarded to allow for model spin-up period. The physics options/schemes used in this calculation include WSM 3-class simple ice as micro physic parameterization, Unified NOAH land-surface, YSU Planetary Boundary Layer, RRTM long wave radiation schemes, and Dhudhia short wave radiation schemes etc. for all the domains whereas the Kain-Fritsch convective parameterization scheme was turned on only for coarse domain (D1).

\section{RESULTS}

Fig. 3 represents the set of spatial distribution of 6 hourlyaccumulated precipitations in and around the Pokhara valley and the Fig. 4 represents the 24 hours averaged total accumulated precipitation distribution pattern on the day of 18 August 2001. 

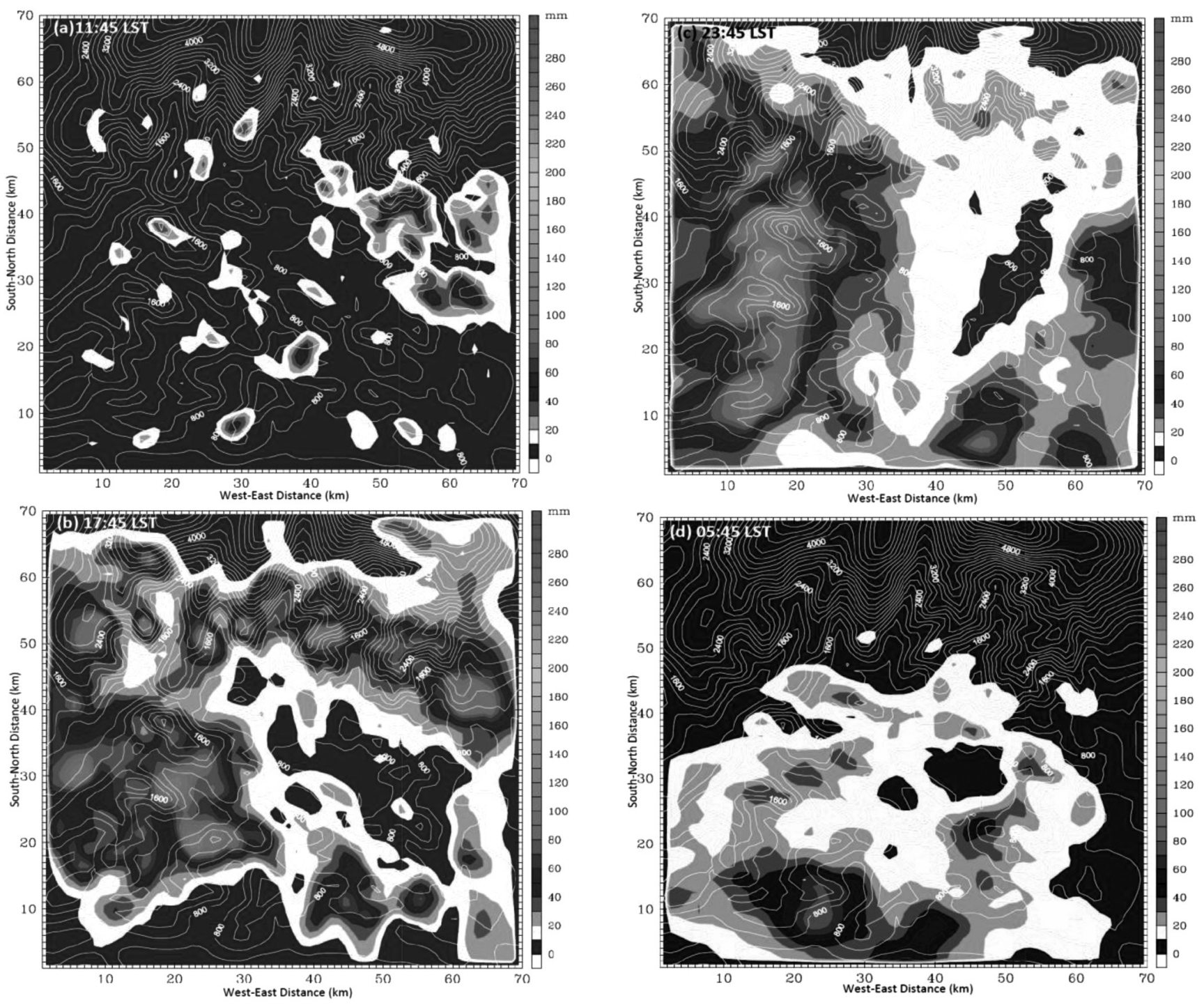

Fig. 3. Simulated six hourly-averaged spatial distribution of accumulated precipitation on the day of 18 August 2001.

Examining the precipitation distribution pattern and the reported value of total rainfall for Pokhara area, it can be said that the simulation has successfully reproduced extreme rainfall situation over the area on the day.

The Fig. 3a shows the spatial distribution of accumulated precipitation within first 6 hours of the day over Pokhara region. The region appears to receive the scattered rainfall ranging from $10-80 \mathrm{~mm}$ in eastern and southern neighboring hilly areas. The remaining areas appear to receive little precipitations. In the afternoon (Fig. 3b) the precipitation intensified greatly over the southwestern and northern hilly areas as well as over the some southern pocket areas where the precipitation amount varies from 40 to $120 \mathrm{~mm}$. However, the central valley area received less than $10 \mathrm{~mm}$ of precipitation during the same period. The precipitation over Lumle and Phewa Lake areas has been predicted to be about 100 and $20 \mathrm{~mm}$, respectively. During the late afternoon (Fig. 3c), the precipitation appears to weaken over the southern slopes of Himalaya range in the north and reaches to about $20 \mathrm{~mm}$ but the precipitation over the southwestern hilly areas further intensified. The accumulated precipitation during the late afternoon until midnight amounts more than 140 to $160 \mathrm{~mm}$. The precipitation over the Pokhara valley also intensified during the period and may reach as much as $20 \mathrm{~mm}$ except over small pocket area around Byas Municipality where precipitation remains less than 10 $\mathrm{mm}$. The southeastern and eastern edge areas might also have received significant precipitation during the period. The accumulated precipitation over these areas ranges from 20 to $60 \mathrm{~mm}$. 


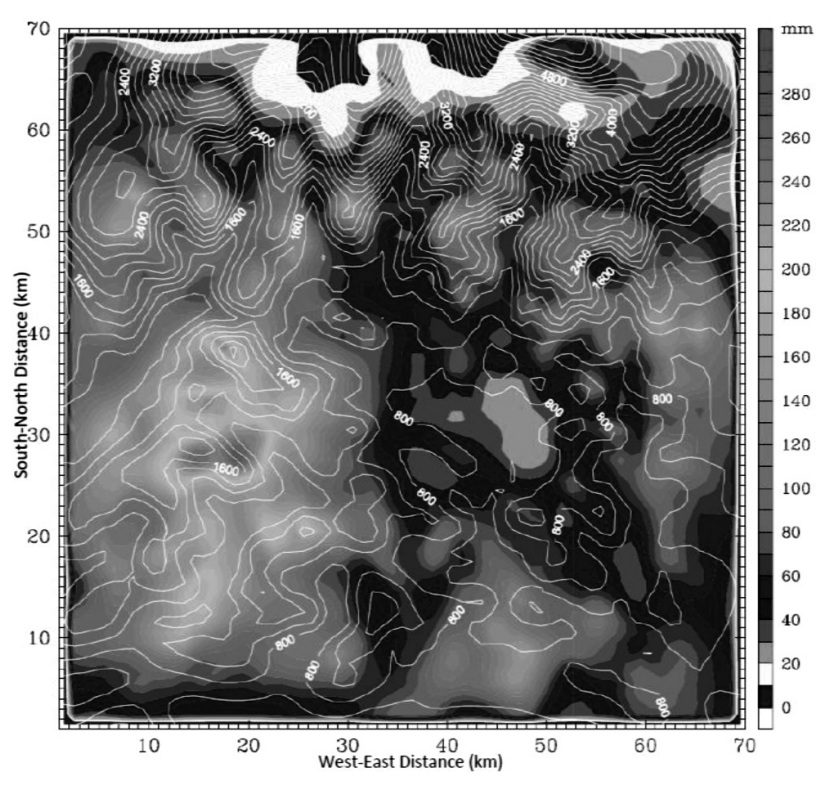

Fig. 4. Spatial distribution of simulated 24 hours averaged total accumulated precipitation over the Pokhara region on day of 18 August 2001.

The last 6 hours indicates the low intensity of rainfall in the Pokhara valley (Fig. 3d). Northern Mountain ranges, foothills, extreme southeastern area and pocket of areas close to center of the valley receive less than $10 \mathrm{~mm}$ of rainfall. Most of the areas including Mt. Panchase receive lesser precipitation ranging from 10-30 mm compared to the south and southeastern hilly areas where close to 70 $\mathrm{mm}$ of precipitation has been predicted.

As can be seen in Fig. 4, the 24 hours averaged spatial distribution pattern of total accumulated precipitation over the Pokhara region suggests that the intensity of precipitation was highest over the western and southwestern hilly areas surrounding the Pokhara valley, particularly, over the Mt. Panchase where occurrence of more than $270 \mathrm{~mm}$ of rainfall has been predicted. Over the southern slopes of the northern surrounding high mountains, eastern and southern areas also received significantly high precipitation amounting more than 200 $\mathrm{mm}$ in some pocket areas. However, the precipitation over the central valley area and over the Phewa Lake is predicted to be less than 80 and $40 \mathrm{~mm}$, respectively.

It seems that model rather underestimated the reported extreme precipitation of about $357 \mathrm{~mm}$ by as much as 87 $\mathrm{mm}$. The difference in the simulated and observed amount of precipitation appears to be natural since model predicts an average of $1 \mathrm{~km}$ square area whereas the observations show the pinpoint value. The pinpoint observation often suffers from local effects that may lead an exceptionally high precipitation. Very high precipitation in one location and no precipitation just few hundred meters away is not uncommon in Himalayan complex terrain. Thus, it can be said that the model has reasonably well captured the essential features of an extreme precipitation event over the truly complex terrain of Pokhara valley.

\section{CONCLUSIONS}

In this study we have examined the WRF model performance in reproducing an extreme precipitation event over a truly complex terrain of Pokhara region of Nepal Himalaya taking the case of record high precipitation that occurred on the day of 18 August 2001. The model predicted essential features of the extreme precipitation over the area although the model slightly underestimated the reported value of precipitation over the area. The intense precipitation over the foothills and medium sized topographical barriers and the lower precipitation over the higher altitudes of towering mountain barriers appear to be consistent with the theory of orographic precipitation. Moreover, the maximum precipitation predicted over windward slope of the Mt. Panchase and over the southern slopes of the northern high mountains and low precipitation over the valley bottom areas strongly supports the theory of orographic precipitation. It appears that incorporation observations of potential meteorological parameters into the simulation via data assimilation will significantly improve the accuracy of model prediction, which was not possible for this study due to the unavailability necessary data to perform assimilation.

\section{ACKNOWLEDGEMENTS}

The support received from the Tribhuvan University and the University Grants Commission, Nepal, are highly acknowledged.

\section{REFERENCES}

Afandi, G.E., Morsy, M. and Hussieny, F.E. 2013. Heavy Rainfall Simulation over Sinai Peninsula Using the Weather Research and Forecasting Model. International Journal of Atmospheric Sciences (Article ID) 241050: 11 .

Acharya, S., Neupane, S., Chapagain, C., Shrestha, R., Acharya, P., Maharjan, S. and Regmi, R.P. 2014. Early Monsoon Time Local Flow Characteristics over the Hetauda Valley and its Implications. Journal of Institute of Science and Technology 19(2): 43-49.

Chen, C.S., Lin, Y.L., Zeng, H.T., Chen, C.Y. and Liu, C.L. 2013. Orographic effects on heavy rainfall events over northeastern Taiwan during the northeasterly monsoon season. Atmospheric Research 122: 310-335. 
Dasari, H.P. and Challa, V.S. 2015. A study of precipitation climatology and its variability over Europe using an advanced regional model (WRF). American Journal of Climate Change 4: 22-39.

Deb, S.K., Srivastava, T.P. and Kishtawal, C.M. 2008. The WRF model performance for the simulation of heavy precipitating events over Ahmedabad during August 2006. Journal of Earth System Science 117(5): 589-602.

Ibrahim, S. and Afandi, G.E. 2014. Short-Range Rainfall Prediction over Nigeria Using the Weather Research and Forecasting Model, Open Journal Of Atmosphereic and Climate Change 1(2): 3850.

Islam, M.N., Das, S. and Uyeda, H. 2010. Calibration of TRMM derived rainfall over Nepal during 19982007. The Open Atmospheric Science Journal 4: 12-23.

Ji, F., Riley, M., Clarke, H., Evans, J.P., Argiieso, D. and Fita, L. 2013. High resolution rainfall projections for the Greater Sydney Region. 20th International Congress on Modelling and Simulation, Adelaide, Australia, 1-6, www. mssanz.org.au/modsim2013.

Kansakar, S.R., Hannah, D.M., Gerrard, J., Rees, G. 2004. Spatial pattern in the precipitation regime of Nepal. International Journal of Climatology 24: 1645-1659.

Lang, T.J. and Barros, A.P. 2002. An investigation of the onsets of the 1999 and 2000 monsoons in central Nepal. Monthly Weather Review 130: 1299-1316.

Lang, T.J. and Barros, A.P. 2004. Winter storms in central himalayas. Journal of the Meteorological Society of Japan 82(3): 829-844.

Maharjan, S. and Regmi, R.P. 2014. Grid Based Temperature and Relative Humidity Distribution Map of The Kathmandu Valley. Journal of Institute of Science and Technology 19(1): 7-13.

Michalakes, J., Chen, S., Dudhia, J., Hart, L., Klemp, J., Middlecoff, J., Skamarock, W. 2001. Development of a Next Generation Regional Weather Research and Forecast Model. Developments in Teracomputing: Proceedings of the Ninth ECMWF Workshop on the Use of High Performance Computing in Meteorology. (eds.) Zwieflhofer, W. and Kreitz, N. World Scientific, Singapore. 269-276p.

Michalakes J, Dudhia J, Gill D, Klemp J, Shamarock W 1998. Design of a next-generation regional weather research and forecast model : Towards
Teracomputing, World Scientific, River Edge, New Jersey. 117-124p.

Nayava, J.L. 1974. Heavy monsoon rainfall in Nepal. Weather 29(12): 443-450.

Nayava JL. 1980. Rainfall in Nepal. The Himalayan Review: Nepal Geographical Society 12: 1-18.

Otkin, J.A. and Greenwald, T.J. 2008. Comparison of WRF model-simulated and MODIS-derived cloud data. Monthly Weather Review 136: $1957-$ 1970.

PANO, 2009. Temporal and spatial variability of climate change over Nepal. Practical Action Nepal Office. 5p.

Regmi, R.P. 2013. Springtime windstorms in the Kathmandu valley and its predictability. Journal of Institute of Science and Technology 18(2): 2836.

Regmi, R.P. 2014a. Aviation over the Jomsom Airport of Nepal as Revealed by Numerical Simulations of Local Flows. Journal of Institute of Science and Technology 19(1): 111-120.

Regmi R.P. 2014b. Aviation Hazard in the sky of Thada as Revealed by Meso-scale Meteorological Modelling. Journal of Institute of Science and Technology 19(2): 65-70.

Regmi, R.P. and Maharjan, S. 2013. Wind Energy Potential of Middle Hills of Nepal Himalaya. World Wind Energy Association, Quarterly Bulletin (Issue) 1: 44-48.

Shrestha, D., Singh, P. and Nakamura, K. 2012. Spatiotemporal variation of rainfall over the central Himalayan region revealed by TRMM Precipitation Radar. ournal of Geophysical Research 117: D22106, doi:10.1029/2012JD018140.

Shrestha, M.L. 2000. Interannual variation of summer monsoon rainfall over Nepal and its relation to Southern Oscillation Index. Meteorology and Atmospheric Physics 75: 21-28.

Skamarock, W. C., Klemp, J.B, Dudhia, J., Gill, D.O., Barker, D.M., Duda, M.G., Huang, X-Y., Wang, W. and Powers, J.G. 2008. A description of the advanced research $W R F$ version 3. NCAR/TN475+STR, NCAR Technical Note. 7p.

Vaid, B.H. 2013. Numerical simulations and analysis of June 16, 2010 heavy rainfall event over Singapore using the WRFV3 Model. International Journal of Atmospheric Sciences (Article ID) 825395: 8. 